\title{
From Romanticism and fiction to reality: Dippel, Galvani, Aldini and "the Modern Prometheus". Brief history of nervous impulse
}

\section{Julio César López-Valdés}

Department of research, Facultad de Medicina de Tampico Dr. Alberto Romo Caballero, Universidad Autónoma de Tamaulipas, Tampico, Tamps., Mexico

\begin{abstract}
Mary Wollstonecraft Godwin, better known as Mary Shelley, and her romantic vision of the world gave life to an endless progeny of literacy stories; also originated the myth of the mortal creator who generate life from science. Unexpectedly the history has been considered as a myth, due to acts grounded in facts of certain "truthful;" such were galvanism and the study of the electrical potential in living beings by the two Italian physicians: Luigi Galvani and Giovanni Aldini. Also, is possible to proclaim direct influence on the work by the European folklore surrounding the theologian, alchemist Johann Konrad Dippel and physician who habited the Frankenstein's Castle from his birth, and further developing the "life elixir." The similarities between the novel and the life of the three historical figures suggests that Mary Shelley, belonging to a socially graceful and educated class, was aware of the scientific dispute over the understanding of electricity. Shelley's creative world, full of gothic and romantic hues, shows direct influence of alchemy speaking of the "spark of life" as well as works published by Galvani and Aldini.
\end{abstract}

KEY WORDS: Luigi Galvani. Giovanni Aldini. Johan Konrad Dippel. Galvanism.

"If science teaches us anything, it teaches us to accept our failures, as well as our successes, with quiet dignity and grace."

From Young Frankenstein script (1974)

Vision and interpretation of science have been quite varied throughout centuries, probably thanks to the direct influence exerted by the necessities, fears and paranoias inherent to each time period. However, in certain cases, there are characteristics and situations that live on as an echo in eternity; such is the case of the work of English writer Mary Wollstonecraft Godwin (1797-1851), better known as Mary Shelley, who, with her romantic vision of the world gave life to an endless progeny of literary stories, and whose writing also originated the myth of the mortal creator who generates life from science ${ }^{1-3}$.

\section{Romanticism and science}

As such, Romanticism was an era of complexity and amazement, not only due to social debacles that took place from day to day, but also due to uncertainty times induced by scientific experimentation, which was increasingly gaining power and influence on society.

Towards the end of the $18^{\text {th }}$ century and the first decades of the $19^{\text {th }}$ century, the idea of matter preservation and the endless struggle to decipher the effect of electricity on the human body were born, which prompted the emergence of great scientists who carried out experiments in dead bodies using newly-appeared technologies $2,4,5$.

Among other things, romantics worried about ethical limits that had to be respected during investigations,

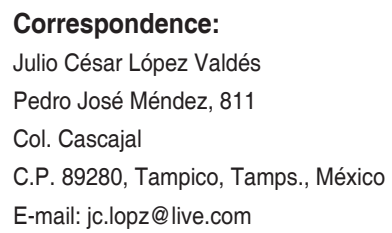

Gac Med Mex. 2018;154:83-87

Contents available at PubMed www.gacetamedicademexico.com 
with inoffensive stories therefore being born based on the ambiguous role science and medicine appeared to play. All these stories ultimately give rise to speculation about ethics and its guidelines in a conscious form for science.

The famous novel Frankenstein or the modern Prometheus, written in 1817, occurs in a period of dynamism and debates, where the story of young Viktor Frankenstein, a Swiss medical student who, during his early journey through the world, is avid of knowledge and attracted to its power and thus he experiments with inanimate forms, which leads him to infuse life to a humanoid being ("the creature") created by his own hands, is narrated ${ }^{3}$.

Finally, terrified by his act, he abandons the nameless being, who turns into a monster for the prejudice of society and the loneliness he is forced to live in.

As it happened throughout the entire Romanticism, the work was profoundly influenced by industrial revolution early stage and natural sciences, especially by medicine and by not-yet-conceptualized electrophysiology.

Although it may appear surprising, the story has evolved to be considered a myth because of acts founded on somehow "truthful" facts that helped to its origin, such as galvanism and the study of electrical potential on human beings, carried out by two Italians: Luigi Galvani (1737-1798) and Giovanni Aldini (17621834), whose investigations were sometimes presented as acts to entertain the masses, maybe in any of them, the young writer ${ }^{5}$.

Similarly, it is possible to claim direct influence on the work by the European folklore of those times that surrounded theologian, alchemist and physician Johann Konrad Dippel (1673-1734), who lived in the Frankenstein Castle since his birth and in addition developed an "elixir of life" from animal-origin oils.

\section{The castle, the scientist and the creature}

In spite of the inexistence of any bibliographic reference within Shelley's work, several authors and scholars claim there is an obvious relationship between the Frankenstein Castle and the novel's antihero. The Frankenstein castle, at $5 \mathrm{~km}$ from Darmstadt, in the south of current Germany, was the house of the Frankenstein free imperial estate and of a large number of noblemen during the $11^{\text {th }}$ century; however, the most controverted and mythical personality was Johann Konrad Dippel, who was born and lived in the castle for several periods during part of the $16^{\text {th }}$ and $17^{\text {th }}$ centuries ${ }^{6,7}$.

Dippel was a descendant of a family of preachers and was the fifth generation devoted to religion and theology. He was taught since an early age by his father, Johann Philip Dippel, and later he was sent to Darmstadt Gymnasium, where he developed his curiosity and intellectual skills.

During his youth, he travelled through Europe, graduated in philosophy at Wittenberg and Strasbourg, developed his love for alchemy and medicine, and attended some sessions imparted at the Giessen University, leaving the rest of his education to his innate intellect. In addition, he got involved in several philosophical-religious disputes?.

After exposing his "universal cure" theory and generating a conflict in Strasbourg, he was blamed for murdering a man in a duel and was therefore expelled from the city and sent back to Giessen. Disappointed by the problems caused by religion, he resumed his alchemy studies with the idea of being the first one to turn led into gold. After the failure of his experiment, he found himself forced to move away to Berlin, where he focused his efforts on the universal cure theory. Finally, he developed the elixir vitae, which later was named "Dippel oil", which was extracted from animal material distillate.

In 1704, while he was working together with Jacob Diesbach, there was a confusion in the preparation of the oil, which resulted in a mixture of Dippel oil and potassium carbonate, which caused the discovery of Prussian blue ${ }^{7,8}$.

Dippel published more than 70 works under the Christianus Democritus pseudonym. In one of his works, Maladies and Remedies of the Life of the Flesh, he mentioned having made studies on transference of the soul and transmigration by means of his oil ${ }^{6,7}$.

Johan Konrad Dippel died at the age of 61 years, on April 25, 1734, at Wittgenstein Castle near Berleburg (Germany), by possible poisoning ${ }^{6}$.

In spite of the inexistence of data of certainty as regards knowledge of the young writer about the Frankenstein Castle and the stories about its singular inhabitant, there are references that place Mary Shelley in a family trip near the Rhine River. According to her diary, she was on a trip in the vicinity of the river on September 2, 1814, together with her sister and Percy Shelley, her future husband, and docked that day's night close to Gernsheim for at least 3 hours ${ }^{8}$. 


\section{Luigi Galvani, the genius tormented by the "spirit"}

Years later, Luigi Galvani, and Italian physician, anatomist, physiologist and physicist native to Bologna, started performing experiments in order to determine the existing relationship between electricity and life. Galvani defended the idea of the existence of two types of electric energy: animal and "common" energy ${ }^{9-13}$.

Due to the need to prove his theory, Galvani conceived an experiment that consisted of using the lower part of a frog's body with the nerves exposed and a metal wire inserted in the spinal canal and connected to a machine of his invention by means of which he applied a mild electric discharge that generated contractions in the batrachian muscles ${ }^{10-14}$. Later, on April 16, 1786, Galvani reproduced the experiment in non-controlled environmental conditions with the purpose to demonstrate the existence of atmospheric electric energy ${ }^{12-14}$. For the scientist, both results demonstrated a close relationship between electricity and life, and in October 30, 1786, Galvani read his conference De Animali Electricitate for the first time at the Bologna Academy of Sciences, thus giving a public explanation of his discoveries ${ }^{10,14,15}$.

Finally, Galvani published the results of his experiments in 1791, within the manuscript De viribus electricitatis in motu musculari. Commentarius, where he arrived to the conclusion of the presence of an "animal electricity" in every living being, as well as a vital fluid that is activated when stimulated by an electric discharge. Similarly, he proposed that the brain generated electricity that is distributed via the internal core of nerves to the muscles. However, scientific debate was not slow in coming. Italian physicist Alessandro Giuseppe Antonio Anastasio Volta (1745-1827), after replicating Galvani's experiments and performing new studies, refuted the animal electricity hypothesis alluding to muscle spasm origin in an electrical fluid produced by external conductors of metallic nature. Towards the end, Galvani published in 1797 a series of five monographs, entitled Memorie sull'electricitá animale, where, after a series of new experiments, he persisted on the hypothesis of animal electricity and vital fluiid ${ }^{10-18}$.

During the following years, European society found itself involved in a series of scientific disputes where great personalities of those days participated, such as naturalist Friedrich Wilhelm Heinrich Alexander Freiherr von Humboldt (1769-1859), chemist Friedrich
Albrecht Carl Gren von Halle (1760-1798) and naturalist Lazzaro Spallanzani, among others ${ }^{14,15}$.

After Luigi Galvani's death, and with the advent of the new century, the race for finding evidences for the origin of "animal electricity" was conquered by Alessandro Volta after reading his speech Memoire sur l'identité d'électrique avec le fluide galvanique at the National Institute of France (1801) upon invitation by Napoleon Bonaparte ${ }^{10,11,15}$.

Galvani's doctrine had broad international influence, to the point that German physician and physiologist Emil Heinrich Du Bois-Reymond (1818-1896) equated it to the social events that took place after the French revolution, half century later. Even when currently we can state that both theories were partially wrong, they were great contemporary advances that enabled important leaps in several fields of science, creating the bases for electrophysiology and nervous impulses, as well as for electromagnetism and Faraday's laws ${ }^{10,14,15}$.

It should be mentioned that Luigi Galvani was a scientifically controverted personality that probably was tormented by shortages and by the need of change that were inherent to those years. Of note, since 200 years prior, Bologna was part of the Pontifical State, until June 18, 1796, when French troops led by Napoleon entered Bologna and declared the fall of the Pontifical state. In addition, many scientists, physicists and religious scholars, among others, believed in the existence of a "vital breath" that animated living beings, and the functioning of which was considered to be different to that of inanimate matter, which made for formal and ideological education of the scientist to be directly influenced by the church.

\section{Giovanni Aldini and deep brain stimulation}

Giovanni Aldini, a faithful advocate of his Uncle Luigi Galvani hypothesis, after the dismissals published by Volta, undertook the task of preserving and spreading the animal electricity theory through Europe and thus he participated in the writing and anonymous publishing of the manuscript Dell'uso e dell'attività dell'arco conduttore nelle contrazioni dei muscoli (1794), where a series of experiments are described without the use of metals, giving rise to a new finding that supported the participation of animal electricity in nervous system functioning ${ }^{5,15,19}$.

During the ensuing years, Giovanni Aldini participated in Galvani's publications through the conduction of several experiments, with his most important contribution being the demonstration of muscle contraction 
by using purified mercury as a link between the femoral nerve and the leg muscles. The explanation of the experiment was published within the second monograph of the work Memorie sull'electricitá animale (1797). Soon after Galvani's death and the proclamation of Volta as winner, Aldini published his work Experiments in the Galvanic fluid (1802), where he explained in detail, by means of illustrations and notes, his results, thus continuing with the scientific-social dispute ${ }^{15,19-21}$.

Aldini was an active extremist in defense of galvanism. He conducted studies in different animals and in humans, with the purpose to demonstrate the relative sensitivity to electric energy at different brain regions; he proposed galvanism as a therapy for psychiatric disorders, and documented (1801) its effects on Luigi Lazzarini, a 27-year old farmer who suffered from major depression ("melancholic madness"). However, his most controverted experiments were a series of demonstrations that took place between January and February 1802, near the Bologna Palace of Justice. In these experiments, Aldini applied electric current to several parts of the bodies of three criminals that had been decapitated one hour prior. The results were similar in all cases: the incredible effect of moving those bodies, producing convulsions and terrifying movements of arms and legs. Aldini reported a duration of the electric effect lasting up to 3 hours after the impulse was applied ${ }^{19,22-28}$.

Over the year 1802, Aldini travelled through Europe diffusing his results, with the purpose to convince the scientific community about the existence of animal electricity, in addition to demonstrating the usefulness of galvanism in the field of medicine. In England, Aldini performed several of his acts in the most renowned hospitals and, finally, on January 18,1803 , at the Royal College of Surgeons of London, he performed his most important exhibition with the remains of recently executed criminal George Foster (1777-1803), who had been hanged little less than one hour prior for the murder of his family. Aldini, with the help of surgeon Joseph Constantine Carpue (1764-1846) and Dr. Thomas Keate (1745-1821), placed a diode of a bimetallic battery and the opposite homologue in the mouth or the rectum of the corpse, allowing electric energy to flow freely. The results were surprising for spectators: there were facial gesticulations with ocular opening, lung insufflation, movement in upper limbs and even convulsions with flexion of the trunk onto the abdomen, giving an appearance of resuscitation ${ }^{14,15,19}$.
The spectacle was reported by the London newspaper The Times (January 22, 1803) and the news caused a strong impression that endured a long period in the minds of scientists and in the general population ${ }^{19}$.

Towards the end of his medical career, Aldini published the book An account of the late improvements in galvanism (1803), which contained the description of the experiment on George Foster's body. Soon after, the French version of the compendium (Précis des expériences galvaniques faites récemment à Londres et à Calais) and the book Essai théorique et experimental sur le galvanisme (1804) were published ${ }^{15,19}$.

As Galvani, Aldani was a personality that was overwhelmed by the events of repression and liberation that took place in those days (French revolution, proclamation of the French Cisalpine Republic, French coalition wars, among others). Unlike Galvani, Giovanni Aldini swore allegiance to Napoleon and his government, thus obtaining greater opportunities and diffusion for his studies.

\section{Conclusions}

The similarity between the novel and the life of the three historical characters suggests that, since Mary Shelley belonged to a socially favored and educated class, she was aware of the scientific dispute over the understanding of electric energy. Shelley's creative world, full of gothic and romantic hues, shows direct influence of alchemy when referring to the "spark of life", as well as of works published by Luigi Galvani and Giovanni Aldini. In addition, within the novel, it is possible to observe allusions to this science by the protagonist (e.g., Paracelsus and Cornelius Agrippa). Furthermore, it makes reference to events that suggest discoveries and personalities of that period. Thereby, the author insinuates that the possible solution to every problem is science.

Just as Dippel, Mary Shelley defends that creation originates from chaos, and that objects are only newly transformed. By naming the work as one of the great titans (Prometheus), Shelley notices the possibility of conceiving man as a titan that grants an enormous present to humanity, but at the same time points at the hecatomb this entails (just as with the titan).

In general, seen from another angle, the work should be considered as a compendium of the sociocultural and scientific events that had taken place with the arrival of the $18^{\text {th }}$ century, as well as the birth of one generation that was to suffer new afflictions 
originated by industrialized society hustle. In several occasions, the "creature" shows glimpses of psychopathic and socially atypical attitudes influenced by depression ("I am mean, because I am miserable"). Similarly, he mentions the feeling of abomination by society towards marginalized people with evident disfigurations (very common in those days owing to industrialization).

\section{References}

1. Pamo-Reyna O. Mary Shelley, Frankenstein y la creación de vida. Disponible en: https://www.researchgate.net/publication/295092438

2. Kallman A. Speciesism in Mary Shelley's Frankenstein (Short Master's thesis in English literature). Lund: Centre for Languages and Literature, Lund University; 2015.

3. Mitra Z. A science fiction in a gothic scaffold: a reading of Mary Shelley's Frankenstein. Rupkatha j. interdiscip. stud. humanit. 2011;3:52-9.

4. Shelley M. Frankenstein o "el moderno Prometeo". Barcelona: Ediciones B; 1991

5. Miscione GP. Las ranas de Galvani, la pila de Volta y el sueño del doctor Frankenstein. Hipótesis, Apuntes Científicos Uniandinos. 2015;(18).

6. Aynsley EE, Campbell WA. Johann Konrad Dippel, 1673-1734. Med Hist. 1962;6:281-6.

7. Kraft A. On the discovery and history of Prussian blue. Bull Hist Chem 2008:33:62-7.

8. Mueller M. Frankenstein - the monster's home? Geschichtsverein Eberstadt/Frankenstein. 2010. Disponible en: http://www.eberstadt-frankenstein.de/content/066_Any_monster_at_home_English_version.pdf

9. De Micheli-Serra A, Iturralde-Torres P, Izaguirre-Ávila R. How electricity was discovered and how it is related to cardiology. Arch Cardiol Mex. 2012;82:252-9.

10. Bresadola M. Medicine and science in the life of Luigi Galvani (17371798). Brain Research Bulletin. 1998;46:367-80.
11. Piccolino M. Luigi Galvani's path to animal electricity. C R Biologies. 2006;329:303-18.

12. Piccolino M. Visual images in Luigi Galvani's path to animal electricity. Journal of The History of the Neurosciences. 2008;17:abstract.

13. Piccolino M. Luigi Galvani and animal electricity: two centuries after the foundation of electrophysiology. Trends Neurosci. 1997;20:443-8.

14. De Micheli-Serra A. Recordando a Luigi Galvani en el bicentenario de su muerte. Gac Med Mex. 1999;135:323-8.

15. Gallone P. La rana de Galvani: anuncio de una nueva era. Electrochimica Acta. 1986;31:1485-90.

16. Stephens $\mathrm{E}$. "Dead eyes open": the role of experiments in galvanic reanimation in nineteenth-century popular culture. Leonardo. 2015;48:276-7.

17. Palacios $L$. Breve historia de la electroencefalografía. Acta Neurol Colomb. 2002;18:104-7.

18. Griffiths A. Tableaux morts: execution, cinema, and galvanistic fantasies. Republics of letters. Disponible en: http://arcade.stanford.edu/sites/default/files/article_pdfs/ROFL_v4_Griffiths_03Pass(2)_0.pdf

19. Parent A. Giovanni Aldini: from animal electricity to human brain stimulation. Can J Neurol Sci. 2004;31:576-84.

20. De Micheli A. En torno a los primeros estudios de electrofisiología. Arch Cardiol Mex 2011;81:337-42.

21. King L. Signor Aldini's notebook. Treasures from the Library 64. Disponible en: http://publishing.rcseng.ac.uk/doi/pdf/10.1308/147363510X505839

22. Kandel $M$, Beis J-M, Le Chapelain L, et al. Non-invasive cerebral stimulation for the upper limb rehabilitation after stroke: a review. Ann Phys Rehabil Med. 2012;55:657-80.

23. Elsenaar A, Scha R. Electric body manipulation as performance art: a historical perspective. Leonardo Music Journal. 2002;12:17-28.

24. Canavero S, Ren X, Kim CY. HEAVEN: the Frankenstein effect. Surg Neurol Int. 2016; 7. Disponible en: http://surgicalneurologyint.com/surgicalint_articles/heaven-the-frankenstein-effect/. DOl:10.4103/2152-7806.190472

25. Rutten WLC. Selective electrical interfaces with the nervous system. Annu Rev Biomed Eng. 2002;4:407-52.

26. Huntington $\mathrm{G}$. Transcranial direct current stimulation: a viable therapeutic option for depression. Res Medica. 2015;23:82-5.

27. Zaghi S, Acar M, Hultgren B, Boggio PS, Fregni F. Noninvasive brain stimulation with low-intensity electrical currents: putative mechanisms of action for direct and alternating current stimulation. The Neuroscientist. 2009;20:1-24.

28. Steinberg R. Between silence and speech: spectres and images in the aftermath of the Reign of Terror. Acta Academica. 2015;47:247-65. 